\section{Copper in Isopods}

IN crustaceans the hepatopancreas is the main organ of enzyme production. In isopods this organ consists of two types of cells which differ in size and were first distinguished by Weber ${ }^{1}$. This author observed in the smaller cells dense clumps of yellowish granules which became the subject of some controversy. Weber thought these granules to be 'enzymogens', a contention which was denied by Frenzel ${ }^{2}$. Patrick ${ }^{3}$ held the granules to represent mucin or mucigens since they could be stained-so she claimed-only with mucin stains. Patane $e^{4}$, on the other hand, found the granule in question to be untouched by mucin-specific histological techniques and he considered them as catabolic products since they gave rfactions characteristic of purine bases.

So far the controversial granules have been o bserved in terrestrial isopods and in Ligia oceanica, a marine isopod which leads a semi-terrestrial life. T'he examination of some of these animals led me to the conclusion that the nature of the granules is quite different from that assumed by previous authors.

In an X-ray spectrophatometric investigation ${ }^{5}$ it was found that terrestrial isopods contain enormous amounts of copper-as set out in Table 1.

Of the population with the highest copper content, Porcellio scaber from Cornwall, several specimens were dissected and their cuticles, intestines and hepatopancreas pooled. The analyses on these samples gave the values shown in Table 2 .

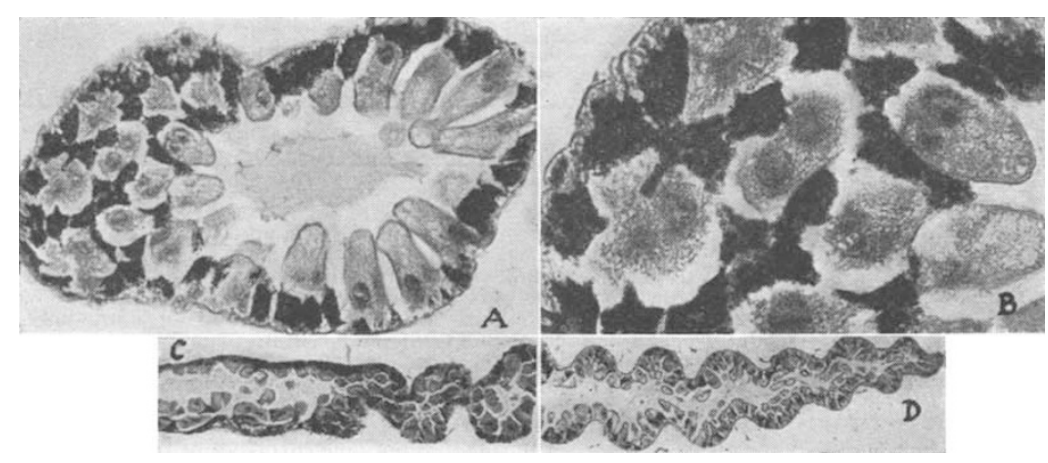

Fig. 1. Sections through one hepatopancreatic tubule of A rmadillidium granulatum Brandt. $A, B$, transverse; $C, D$, sagittal through proximal $(C)$ and distal $(D)$ portion. Staining: rubeanic acid and ham-alum. The copp

The copper content of the hepatopancreas in this species is the highest ever reported for any organ of an animal.

In sections of the hepatopancreas of Armadillidium granulatum stained with rubeanic acid (dithiooximide) ${ }^{6}$ the copper shows as dense black masses occurring intercellularly and in the small hepatopancreatic cells (Fig. 1). The large cells are free of copper which agrees with the findings of the earlier authors $^{1-4}$ that in the large cells granules do not occur. There can be scarcely any doubt that the granules observed by these authors are identical with, or contain, the copper made visible by staining with rubeanic acid.

The copper in the hepatopancreas of the animals investigated cannot be present as "specific protein copper' since in such a state, as defined by Zuckerkandl', it would not react with a chelating agent like
dithio-oximide. Moreover, the copper content of the hæmocyanin molecule, the cuproproteid most likely

\begin{tabular}{|c|c|c|c|}
\hline Species & Source & $\begin{array}{l}\text { Copper (percentage } \\
\text { of dry weight of } \\
\text { whole animals) } \\
\text { (range and mean) }\end{array}$ & $\begin{array}{c}\text { No. of } \\
\text { analyses }\end{array}$ \\
\hline $\begin{array}{l}\text { Porcellio scaber Ltr. } \\
\text { Porcellio scaber Ltr, } \\
\\
\text { Porcellio scaber Ltr. } \\
\text { Armadillidium } \\
\text { granulatum } \mathrm{Br} \text {. } \\
\text { Armadillidium } \\
\text { klugit Br. } \\
\text { Armadillidium } \\
\text { vulgare Latr. } \\
\text { Cylisticus convexus } \\
\text { B.I. } \\
\text { Syspastus brevi- } \\
\text { cornis Ebner }\end{array}$ & $\begin{array}{l}\text { Suez, Egypt } \\
\text { Vienna, } \\
\text { Austria } \\
\text { Cornwall } \\
\text { Spain } \\
\text { Spalato, } \\
\text { Yugoslavia } \\
\text { Vienna } \\
\text { Vienna } \\
\text { Elba }\end{array}$ & $\begin{array}{l}0.039-0.043(0.041) \\
0.096-0.118(0.106) \\
0.047-0.088(0.063) \\
0.074-0.088 \\
0.048-0.050 \\
0.051 \\
0.026-0.031(0.028)\end{array}$ & $\begin{array}{l}5 \\
3 \\
4 \\
2 \\
2 \\
1 \\
3\end{array}$ \\
\hline
\end{tabular}

Table 2

\begin{tabular}{|l|c|}
\hline \multicolumn{1}{|c|}{ Organ } & Copper (percentage of dry weight) \\
\hline Cuticle & $<0 \cdot 005$ \\
Intestine + hepatopancreas & $0 \cdot 635$ \\
Intestine & 0.076 \\
Hepatopancreas & $1 \cdot 43$ \\
\hline
\end{tabular}

to occur in these animals, is only $0 \cdot 18-0.22$ per cent ${ }^{8}$, thus even if the hepatopancreas consisted exclusively of hæmocyanin its copper content should be lower by almost one order of magnitude than it actually is. To account for its reaction with rubeanic acid the copper in the hepatopancreas of the isopods must be present in a reactive, easily dis sociable state (the "cuivre naturellement réactive" of Zuckerkandl). How in this case toxicity is avoided and what the functions of these extraordinarily large amounts of copper could be remains to be investigated. Although up to now the occurrence of hæmocyanin in crustaceans has been proved only in stomatopods and decapods ${ }^{9}$ it would not be unreasonable to expect the presence of this pigment in isopods, in which case part of the copper in the hepatopancreas might be in store for the synthesis of hæmocyanin.

All the isopods examined are reared on a diet of leaves and carrots and were kept in laboratory culture from 6 months to 6 years. Most of the isopods studied were collected and kept in culture by Prof. W. Kühnelt, whose co-operation in this investigation is gratefully acknowledged. The X-ray analyses were performed on mature, non-ovigerous, non-moulting animals in March 1961 by Dr. H. Makart at the Mineralogical Institute of the University, Vienna.

\section{Zoologisches Institut der Universität,} Wien.

1 Weber, M., Arch. Mikr. Anat., 17, 385 (1880).

${ }^{2}$ Frenzel, J., Mitt. Zool. Station Neapel, 5, 50 (1884).

- Patrick, D., Brit. J. Exp. Biol., 4, 27 (1926).

4 Patané, L., Arch. Zool. Italiano, 20, 303 (1934).

- Wieser, W., and Makart, H., Z. Naturforschung (in the press).

- Okamoto, K., and Utamura, M., Act. Schol. Med. Univ. Imp. Kyoto. 22, 573 (1938).

Z Zuckerkandl, E., Ann. Inst. Océanogr., 88, 1 (1960).

- Redfield, A., Biol. Rev., 9, 176 (1934).

- Goodwin, T. W., in The Physiology of Crustacea, 1, 101 (Academic oodwin, T. W., in The Physiology of Crustacea
Press, Inc., Now York and London, 1960). 